\title{
Autism and MMR Vaccination or Thimerosal Exposure: An Urban Legend?
}

An 'urban legend' is an apocryphal story often told in the form of a cautionary tale that is related or transmitted as if true. ${ }^{1}$ The tale is plausible enough to be believable and indeed is a type of modern folklore that represents the beliefs of ordinary people. Frequently, the legend addresses a vexing aspect of modern life and carries the moral message that new technologies may ultimately prove to be a hazard. Mass media, including the internet, may serve to propagate and establish an urban legend as "truth", however careful examination of the legend's origin and its contents ultimately reveals it to be false and without basis.

The belief that either MMR vaccination or excessive thimerosal exposure may be causally linked to the occurrence of an autistic spectrum disorder has many of the features of an urban legend. For MMR vaccination it originates in a single small study of 12 children published in the Lancet in 1998, ${ }^{2}$ whose essential conclusion was later retracted by ten of its coauthors. ${ }^{3}$ This article serves as the core of the "vaccination and autism' legend that is now believed to be true by a majority of parents surveyed. ${ }^{4}$ For thimerosal, the legend's origin lies not in a scientific article per se, but in a theoretical proposal published in Medical Hypothesis in 2001.5 However, as systematically surveyed by Doja and Roberts ${ }^{6}$ in this issue of the Canadian Journal of Neurological Sciences, the vast preponderance of epidemiological data subsequently collected in a variety of geographic settings, utilizing a number of investigative approaches, refutes any causal link between autism and either prior MMR vaccination or excessive thimerosal exposure.

Particularly impressive are the results obtained from large datasets in Denmark, ${ }^{7}$ the United Kingdom, ${ }^{8-10}$ Finland, ${ }^{11}$ Sweden, ${ }^{12}$ United States, ${ }^{13}$ Japan $^{14}$ and most recently Canada itself $^{15}$ that each independently have refuted any MMR vaccination and autism causal association. Other systematic reviews, to which that of Doja and Roberts can be appended, have supported these conclusions. ${ }^{16-18}$ Furthermore, recent rigorous and independent molecular biologic investigations of one corollary hypothesis, that of the persistence of the measles virus in autistic children, have yielded negative results and unmasked more methodological flaws in the original work. ${ }^{19,20}$ Similarly, epidemiologic studies have refuted, utilizing varying approaches and analyses (cohort and ecological), convincingly any link between excessive thimerosal exposure and later autism. ${ }^{15,21-26}$ Biological studies have also not validated any thimerosal and autism link. ${ }^{27,28}$

Yet despite the overwhelming scientific epidemiologic evidence and the lack of any plausible scientific hypothesis as to why the MMR vaccine or thimerosal should cause autism, the belief stubbornly persists. A question is why? Perhaps the answer lies in the nature of an autistic spectrum disorder and our present lack of understanding of its precise biological basis.

Originally described by Kanner in the 1940's, autistic spectrum disorders are a heterogeneous group of neurodevelopmental disabilities that share an early age of onset and qualitative, as well as quantitative, impairments in language development and reciprocal social interactions. ${ }^{29}$ Often the disorder is heralded by the loss of previously acquired skills and frequently the affected children are emotionally unaware or inappropriate, prone to repetitive and at times self-injurious behaviours (stereotypies) and an obsessive desire for sameness or routine. ${ }^{30}$ Rarely does a detailed medical evaluation reveal a cause for the child's autism which is a source of tremendous frustration for both families and physicians. ${ }^{31}$ Adding to the parent's frustration is the frequent lack of any reciprocal love they receive from their child despite their own parental devotion and pre-occupation with the child's disability. In addition, many parents have incorporated guilt for their child's condition that can be traced to the early misconception (also stubbornly persistent) that related this perplexing neurobehavioral syndrome to parental child rearing practices. ${ }^{32}$

For frustrated often guilt ridden parents, vaccines given coincidentally at a time that is related to their recall of the onset of symptoms in their child, offers a plausible causal attribution. Though a modern technological innovation that collectively represents the single greatest advance in 20th Century pediatric practice, vaccines have been viewed with suspicion for years by a scientifically naïve subset of the general population. ${ }^{33}$ Indeed, much of the MMR-thimerosal and autism story resembles that previously encountered in the putative link between cellular pertussis vaccine and infantile spasms/childhood encephalopathy. ${ }^{34}$ This link was also found to be patently untrue.

Urban legends are usually harmless and indeed amusing to both storyteller and listener. However, a sad outcome of the autism and vaccination urban legend is the consequence of declining vaccination rate as the scourge of vaccine preventable infectious diseases have faded from the collective memory of the general population. ${ }^{35}$ The result of this have been welldocumented outbreaks of vaccine preventable diseases, resulting unfortunately in some deaths. ${ }^{35}$ Beliefs in the "mercury poisoning" hypothesis in autism has led to the uncontrolled use of chelation therapies that are not indicated, of unproven efficacy, and potentially dangerous as illustrated by the recent death of a young boy. ${ }^{36}$ Furthermore, another sad outcome is the diversion of scarce expertise and research dollars to refuting a 
legend based on fallacy and innuendo. Parents of autistic children deserve answers to the question; "Why their child?" The answers to such a question lies not in chasing phantoms and legends, but rather pursuing early promising leads offered by recent advances in molecular genetics ${ }^{37}$ and neuro-imaging. ${ }^{38}$

Michael Shevell, Eric Fombonne Montreal, Quebec, Canada

\section{ACKNOWLEDGEMENTS}

MS is grateful for the support of the Montreal Children's Hospital (MCH) Foundation and Y Country Camp (YCC) during the writing of this manuscript. EF is a Canada Research Chair of the Canadian Institute of Health Research. Alba Rinaldi provided the necessary secretarial assistance.

\section{REFERENCES}

1. http://en.wikipedia.org/wiki/urban_legend. [Cited 2006 Aug 14].

2. Wakefield AJ, March SH, Anthony A, Linnell J, Casson DM, Malik $\mathrm{M}$, et al. Ileal-lymphoid-nodular hyperplasia, non-specific colitis, and pervasive developmental disorder in children. Lancet. 1998:351:637-41.

3. Murch SH, Anthony A, Casson DH, Malik M, Berelowitz M, Dhillon AP, et al. Retraction of an interpretation. Lancet. 2004;363:750.

4. Halsey N, Hyman S. Conference Writing Panel. Measles, mumps and rubella vaccine and Autism spectrum disorder. Report from the New Challenges in Childhood Immunization Conference convened at Oak Brook, Illinois, June 12-13, 2001. Pediatrics. 2001;107:1-23.

5. Bernard S, Enayati A, Redwood L, Roger H, Binstock T. Autism: a novel form of mercury poisoning. Med Hypotheses. 2001;56:462-71.

6. Doja A, Roberts W. Immunizations \& autism: a review of the literature. Can J Neurol Sci. 2006;33:341-346.

7. Madsen KM, Hviid A, Vestergaard M, Schendel D, Wohlfahrt J, Thorsen $\mathrm{P}$, et al. A population-based study of measles, mumps, and rubella vaccination and autism. NEJM. 2002;347:1477-82.

8. Taylor B, Miller E, Farrington CP, Petropoulos MC, Faust-Mayaud I, et al. Autism and measles, mumps, and rubella vaccine: no epidemiological evidence for a causal association. Lancet. 1999;353:2026-9.

9. Chen W, Landau S, Sham P, Fombonne E. No evidence for links between autism, MMR and measles virus. Psychol Med. 2004;34:543-53.

10. Smeeth L, Cook C, Fombonne E, Heavey L, Rodrigues LC, Smith $\mathrm{PG}$, et al. MMR vaccination and pervasive developmental disorders: a case-control study. Lancet. 2004;364:963-9.

11. Makela A, Nuorti JP, Petola H. Neurologic disorders after measlesmumps-rubella vaccination. Pediatrics. 2002;110:957-63.

12. Gillberg C, Heijbel H. MMR and autism. Autism. 1998;2:423-4.

13. Dales L, Hammer SJ, Smith NJ. Time trends in autism and MMR immunization coverage in California. JAMA. 2001;286:1183-5.

14. Honda H, Shimizu Y, Rutter M. No effect of MMR withdrawal on the incidence of autism: a total population study. J Child Psychol Psychiatry. 2005;46:572-9.

15. Fombonne E, Zakarian R, Bennett A, Meng L, McLean-Heywood D. Pervasive developmental disorders in Montreal, Quebec, Canada. Prevalence and links with immunizations. Pediatrics. 2006;118:e139-50.

16. Institute of Medicine. Immunization Safety Review: Vaccines and Autism. Washington, DC: National Academies Press; 2004.

17. Smeeth L, Rodrigues LC, Hall AJ, Fombonne E, Smith PG. Evaluation of adverse effects of vaccines: the case-control approach. Vaccine. 2002;20:2611-7.
18. Fombonne E. Autism \& immunization. In: Encyclopedia on early childhood development. Montreal, 2006. p.1-8.

19. Afzal MA, Ozoemena LC, O'Hare A, Kidger KA, Bentley ML, Minor PD. Absence of detectable measles virus genome sequence in blood of autistic children who have had their MMR vaccination during the routine childhood immunization schedule of UK. J Med Virol. 2006;78:623-30.

20. D'Scouza Y, Ward B, Fombonne E. No evidence of persisting measles virus in peripheral blood mononuclear cells from children with autism spectrum disorder. Pediatrics. (In Press).

21. Andrews N, Miller E, Grant A, Stowe J, Osborne V, Taylor B. Thimerosal exposure in infants and developmental disorders: a retrospective cohort study in the United Kingdom does not support a causal association. Pediatrics. 2004;114:584-91.

22. Heron J, Golding J. Thimerosal exposure in infants and developmental disorders: a prospective cohort study in the United Kingdom does not support a causal association. Pediatrics. 2004; 577-83.

23. Hviid A, Stellfeld M, Wohlfahrt J, Melbye M. Association between thimerosal-containing vaccine and autism. JAMA. 2003;290: 1763-6.

24. Verstraeten T, Davis RL, DeStefano F, Lieu TA, Rhodes PH, Black SB, et al. Safety of thimerosal-containing vaccines: a two-phased study of computerized health maintenance organization databases. Pediatrics. 2003;112:1039-48.

25. Madsen KM, Lauritsen MB, Pedersen CB, Thorsen PB, Plesner $\mathrm{AM}$, Andersen $\mathrm{PH}$, et al. Thimerosal and the occurrence of autism: negative ecological evidence from Danish populationbased data. Pediatrics. 2003;112:604-6.

26. Stehr-Green P, Tull P, Stellfeld M, Mortenson PB, Simpson D. Autism and thimerosal-containing vaccines: lack of consistent evidence for an association. AM J Prev Med. 2003;25:101-6.

27. Parker SK, Schwartz B, Todd J, Pickering LK. Thimerosalcontaining vaccines and autistic spectrum disorder: a critical review of published original data. Pediatrics. 2004;114:793-804.

28. Ip P, Wong V, Ho M, Lee J, Wong W. Mercury exposure in children with autistic spectrum disorder: case-control study. J Child Neurol. 2004;19:431-4.

29. American Psychiatric Association. Diagnostic and statistical manual of mental disorders, 4th ed. Washington D.C.: American Psychiatric Association; 1994.

30. Filipek PA, Accardo PA, Baranek GT, Cook EH Jr, Dawson G, Gordon B, et al. The screening and diagnosis of autistic spectrum disorders. J Aut Dev Dis. 1999;29:439-84.

31. Shevell MI, Majnemer A, Rosenbaum P, Abrahamowicz M. Etiologic yield of autistic spectrum disorders: a prospective study. J Child Neurol. 2001;16:509-12.

32. Hiotz DG, Wojnr A, Filipek PA. Autistic spectrum disorders. In: Swaiman K, Ashwal S, Ferreir M, editors. Pediatric Neurology: Principle and Practice (4th Ed). Philadelphia: Mosby Elsevier; 2006. p. $905-936$.

33. Salmon DA, Haber M, Gangarosa EJ, Phillips L, Smith NJ, Chen RT. Health consequences of religious and philosophical exemptions from immunization laws: individual and societal risk of measles. JAMA. 1999;282:47-53.

34. Griffin MR, Ray WA, Mortimer EA, Fenichel GM, Schaffer W. Risk of seizures and encephalopathy after immunizations with the diphtheria-tetanus-pertussis vaccine. JAMA. 1990;263:1640-45.

35. Jansen VA, Stollenwerk N, Jensen HJ, Ramsay ME, Edmunds WJ, Rhodes CJ. Measles outbreaks in a population with declining vaccine uptake. Science. 2003;301:804.

36. Shannon M, Levy S, Sandler A. Chelation therapy neither safe nor effective as autism treatment. AAP news 2001:63.

37. Muhle R, Trentacose SV, Rapin I. The genetics of autism. Pediatrics 2004;113. Available from: www.pediatrics.org/cgi/content/full/ 113/5/e472.

38. Helsat MR, Caviness Jr VS. Neuroanatomy and imaging studies. In: Autism: a neurological disorder of early brain development. London: Mckneill Press; 2006. p.115-40. 